\title{
SUSCEPTIBILITY OF ARCOBACTER BUTZLERI TO HEAVY METALS
}

\author{
Laura Otth; Gabriela Solís; Myra Wilson; Heriberto Fernández*
}

Institute of Clinical Microbiology, Universidad Austral de Chile, Valdivia, Chile

Submitted: January 31, 2005; Returned to authors for corrections: August 04, 2005; Approved: September 20, 2005

\begin{abstract}
The susceptibility of 50 strains of Arcobacter butzleri isolated from chicken liver [12], mussels [18], river water [6] and bovine [5], duck [2] and pelicans [7] feces to mercury ( $\mathrm{Hg}$ ), chromium (Cr), silver (Ag), nickel $(\mathrm{Ni})$, cobalt $(\mathrm{Co})$, iron $(\mathrm{Fe})$, manganese $(\mathrm{Mn})$, molybdenum $(\mathrm{Mo})$ and lead $(\mathrm{Pb})$ was determined. All the strains were resistant to $\mathrm{Mo}, \mathrm{Mn}, \mathrm{Ni}, \mathrm{Co}, \mathrm{Pb}$ and $\mathrm{Fe}$ and susceptible to $\mathrm{Hg}, \mathrm{Ag}$ and $\mathrm{Cr}$. MIC values showed high variability, indicating a non homogeneous behavior among the strains.
\end{abstract}

Key words: Arcobacter butzleri, heavy metals, resistance

Arcobacter butzleri is an emerging pathogen that has been associated with abortion and enteritis in animals and with diarrhea and bacteremia in adults and children. This Arcobacter species seems to be the most frequent in human beings. $A$. butzleri recognizes a wide reservoir range, being isolated from domestic and free living mammals and birds, from shellfish and environmental water bodies as well. It has been suggested that water may play an important role in the transmission of these organisms $(6,12)$.

Thus, $A$. butzleri seems to be an ubiquitous microorganism that can be isolated from the environment, animals and also in association with infectious processes in human beings $(5,6,7,9,12)$. However, many of the biological characteristics of this bacterium including the growth in the presence of heavy metals remain unknown. In fact, it seems that there are no references in the literature about the susceptibility or resistance of A. butzleri to heavy metals. Information is restricted to Campylobacter, $(4,13)$, their formerly taxonomic description, and limited to cadmium chloride.

Since A. butzleri is an emerging pathogen frequently recovered from environmental waters that could be contaminated with heavy metals, the susceptibility of $50 \mathrm{~A}$. butzleri strains to nine heavy metal compounds was studied. The strains were isolated from chicken liver for human consumption [12], mussels [18], river water [6] and feces obtained from bovines [5], ducks [2] and pelicans [7].
The susceptibility to heavy metals was assessed using an adaptation of the double dilution agar method for determining antibiotics minimal inhibition concentration (MIC). In brief, series of Mueller-Hinton agar plates containing dilutions of salts of the assayed heavy metals were prepared. The following heavy metals salts and concentration ranges were used $\mathrm{HgCl}_{2}, \mathrm{AgNO}_{3}$, $\mathrm{K}_{2} \mathrm{CrO}_{4}(0.01-0.16 \mathrm{mmol} / \mathrm{L}), \mathrm{FeSO}_{4}, \mathrm{~Pb}\left(\mathrm{C}_{2} \mathrm{H}_{2} \mathrm{O}_{2}\right), \mathrm{NiSO}_{4}(1-16$ $\mathrm{mmol} / \mathrm{L}), \mathrm{MnSO}_{4}, \mathrm{NaMoSO}_{4}$ and $\mathrm{CoO}(5-80 \mathrm{mmol} / \mathrm{L})$.

The plates were inoculated using a Steers replicator, depositing $0.001 \mathrm{~mL}$ of a suspension of each strain in Arcobacter broth. Inocula were prepared diluting a $48 \mathrm{~h}$ broth culture to a relation 1:5. The plates were incubated at $26^{\circ} \mathrm{C}$, during $48 \mathrm{~h}$ under aerobic conditions. The lowest heavy metal concentration producing complete inhibition of macroscopic growth was considered as MIC. Following Mohammad's (8) recommendations, a strain was considered resistant when it was able to grow at a concentration of $1 \mathrm{mmol} / \mathrm{L}$ or more.

As shown in Table 1, all strains were susceptible to mercury, silver and chrome salts and resistant to the other heavy metals salts. $\mathrm{HgCl}_{2}$ was the most active compound inhibiting $28 \%$ of the strains at a concentration $\leq 0.01 \mathrm{mmol} / \mathrm{L}$ whereas $\mathrm{NaMoSO}_{4}$ and $\mathrm{CoO}$ exhibited the lowest inhibitory activity.

In other bacteria, like Pseudomonas sp., resistance to chrome and mercury is codified by plasmids (3). Since all the strains in the present study were susceptible to chrome and mercury salts, it is possible to infer that they do not carry this kind of plasmids.

*Corresponding Author. Mailing address: Institute of Clinical Microbiology, Universidad Austral de Chile, PO Box 567, Valdivia, Chile. Fax: (+5663)293300. E-mail: hfernand@uach.cl 
Table 1. Minimal inhibitory concentrations and resistance (\%) of 50 strains of arcobacter butzleri to nine heavy metals salts

\begin{tabular}{|c|c|c|c|c|c|c|c|c|c|c|c|}
\hline & & & & M. & I. $\mathrm{mcg} / \mathrm{mL}$ & C. & & & & & \\
\hline Metal salt of & $\begin{array}{l}\leq 0.01 \\
\mathrm{~N} / \%\end{array}$ & $\begin{array}{c}0.02 \\
\mathrm{~N} / \%\end{array}$ & $\begin{array}{c}0.04 \\
\mathrm{~N} / \%\end{array}$ & $\begin{array}{c}0.08 \\
\mathrm{~N} / \%\end{array}$ & $\begin{array}{l}0.016 \\
\mathrm{~N} \% \%\end{array}$ & $\begin{array}{c}4 \\
\mathrm{~N} / \%\end{array}$ & $\begin{array}{c}8 \\
\mathrm{~N} \% \%\end{array}$ & $\begin{array}{c}10 \\
\mathrm{~N} \% \%\end{array}$ & $\begin{array}{c}20 \\
\mathrm{~N} / \%\end{array}$ & $\begin{array}{l}\geq 80 \\
\mathrm{~N} \% \%\end{array}$ & $\begin{array}{c}\% \text { of } \\
\text { resistance }\end{array}$ \\
\hline Mercury & $14 / 28$ & $22 / 44$ & $13 / 26$ & $1 / 2$ & & & & & & & 0 \\
\hline Silver & & & $13 / 26$ & $37 / 74$ & & & & & & & 0 \\
\hline Chrome & & & $11 / 22$ & $33 / 66$ & $6 / 12$ & & & & & & 0 \\
\hline Nickel & & & & & & 49/98 & $1 / 2$ & & & & 100 \\
\hline Lead & & & & & & & $50 / 100$ & & & & 100 \\
\hline Iron & & & & & & & $50 / 100$ & & & & 100 \\
\hline Manganese & & & & & & & & $30 / 60$ & $20 / 40$ & & 100 \\
\hline Molybdenum & & & & & & & & & & $50 / 100$ & 100 \\
\hline Cobalt & & & & & & & & & & $50 / 100$ & 100 \\
\hline
\end{tabular}

On the other hand, chrome, mercury and silver compounds are used as disinfectants. The high susceptibility of A. butzleri strains to salts of these three metals leads to speculate that they could be highly susceptible to disinfectants having those metals in their formulation. Studies in order to determine the susceptibility of A. butzleri to different disinfectants are currently being carried out in our laboratory.

Bacteria can use some metals, like cobalt and nickel, as micronutrients, in redox processes, as components of various enzymes and in the osmotic pressure regulation, (2), which can explain in part the resistance observed in A. butzleri to those heavy metals. In the same way, the high resistance observed to $\mathrm{FeSO}_{4}$ could be explained because iron is an essential nutrient for bacterial growth and plays a substantial role in cellular respiration as an important component of citochromes and electron transporting proteins (1). Resistance to cobalt, nickel and lead could be due to plasmids (3) but the resistance mechanisms to heavy metals remain unknown in $A$. butzleri.

An important number of the strains under study have been isolated from mussels (18/36\%) and river water (6/12\%). In earlier studies, Paredes (10) established that low concentrations of lead and nickel could be found in mussels of our region, whereas Quiroz et al. (11) demonstrated the presence of several heavy metals in Valdivia river, located at $73^{\circ} 11^{\prime} \mathrm{W}, 39^{\circ} 46^{\prime} \mathrm{S}$.

Further studies are needed for a better understanding of the resistance of A. butzleri to heavy metals as well as to establish if the environmental presence of heavy metals compounds could be related to this resistance.

\section{ACKNOWLEDGMENTS}

This work received financial support from Grants FONDECYT 1030245 and DID-UACh S-200401.

\section{RESUMO}

\section{Sensibilidade de Arcobacter butzleri a metais pesados}

Arcobacter butzleri é um bacilo Gram negativo de caráter zoonótico, pertencente à Família Campylobacteraceae, que tem sido associado a diarréia e septicemia no ser humano. A susceptibilidade de 50 amostras de A. butzleri isoladas de fígados de frango [12], mariscos [18], água de rio [6] e fezes de bovinos [5], patos [2] e pelicanos [7] aos metais pesados mercúrio $(\mathrm{Hg})$, cromo $(\mathrm{Cr})$, prata $(\mathrm{Ag})$, níquel $(\mathrm{Ni})$, cobalto $\mathrm{Co})$, ferro $(\mathrm{Fe})$, manganês $(\mathrm{Mn})$, molibdênio (Mo) e chumbo $(\mathrm{Pb})$ foi determinada. Todas as amostras foram resistentes a Mo, Mn, $\mathrm{Ni}, \mathrm{Co}, \mathrm{Pb}$ e Fe, sendo susceptíveis a $\mathrm{Hg}, \mathrm{Ag}$ e $\mathrm{Cr}$. Os valores das CIM apresentaram alta variabilidade indicando um comportamento não homogêneo entre as amostras.

Palavras-chave: Arcobacter butzleri, metais pesados, resistência

\section{REFERENCES}

1. Amaro, C.; Aznar, R.; Alcaide, E.; Lemos, M.L. Iron-binding compounds and related outer membrane proteins in Vibrio cholerae non-O1 strains from aquatic environments. Appl. Environ. Microbiol., 56, 2410-2416,1990

2. Bruins, M.R.; Kapil, S.; Oehme, F.W. Microbial resistance to metals in the environment. Ecotoxicol. Environ. Saf., 45, 198-207, 2000

3. Cervantes, C.; Silver, S. Sistemas de resistencia a metales en Pseudomonas. Rev. Lat.-Amer. Microbiol., 38, 45-64, 1996.

4. Epoke, J.; ObI, C.L.; Coker, A.O. In vivo effect of cadmium chloride on intestinal colonization of rats by Campylobacter jejuni. East. Afr. Med. J., 69, 609-701,1992.

5. Fernandez, H.; Rojas, X.; Gajardo, T. Primer aislamiento de Arcobacter cryaerophilus a partir de um aborto bovino em Chile. Arch. Méd. Vet., 32, 111-114, 1995. 
6. Jacob, J.; Woodward, D.; Feurpfeil, I.; Johnson, W.M. Isolation of Arcobacter butzleri in Raw Water and Drinking Water Treatment Plants in Germany. J. Hyg. Umweltmed., 20, 189-198, 1998.

7. Kiehlbauch, J.A.; Brenner, J.; Nicholson, M.A.; Baker, C.N.; Patton, CH.M.; Steiferwalt, A.G.; Wachsmuth, K. Campylobacter butzleri $s p$. nov. Isolates from Humans and Animals with Diarrheal Illness. J. Clin. Microbiol., 29, 376-385, 1991.

8. Mohammad, R.S. Plasmid mediated metal and antibiotic resistance in Pseudomonas aeruginosa strains isolated from burn patients. Med. J. Islam Rep. Iran, 16, 159-163, 2002.

9. On, S.L.; Jensen, T.K.; Bille-hansen, V.; JorsaL, S.E.; Vandamme, P. Prevalence and diversity of Arcobacter spp. isolated from the internal organs of spontaneous porcine abortions in Denmark. Vet. Microbiol., 85, 159-67, 2002.
10. Paredes, M. T. Determinación de metales pesados en dos especies de bivalvosdel estuario de Valdivia y la Bahía de Corral. Valdivia, Chile. Tesis de Grado. Escuela de Biología Marina. Universidad Austral de Chile. 1998. 54 p.

11. Quiroz, E.; Jara, J.; Aguilera A. Metales en el área estuarial de Valdivia. IV Encuentro Científico del Medioambiente, Valdivia, Chile. 1992. p.786.

12. Rice, E.W.; Rodgers, M.R.; Wesley, I.V.; Johnson, C.H.; Tanner, S.A. Isolation of Arcobacter butzleri from ground water. Lett. Appl. Microbiol., 28, 31-35, 1999.

13. Stern, N.J.; Kazmi, S.U.; Roberson, B.S.; Ono, K.; Juven B.J. Response of Campylobacter jejuni to combinations of ferrous sulphate and cadmium chloride. J. Appl. Bacteriol., 64, 247-55, 1988. 